\title{
The Gebra Slide: a submarine slide on the Trinity Peninsula Margin, Antarctica
}

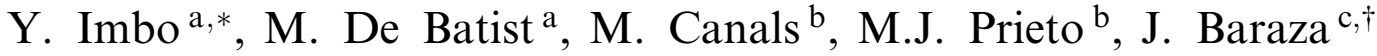 \\ a Renard Centre of Marine Geology - RCMG, Ghent University, Ghent, Belgium \\ b Consolidated Research Group on Marine Geosciences, University of Barcelona, Barcelona, Spain \\ c Consolidated Research Group on Marine Geosciences, Institute of Marine Sciences, CSIC, Barcelona, Spain
}

Received 29 November 2001; accepted 20 November 2002

\begin{abstract}
A large submarine slide - the Gebra Slide - has been discovered on the continental margin of Trinity Peninsula, Central Bransfield Basin, Antarctic Peninsula. The slide scar is clearly expressed in the bathymetry and is cut into the toe of the glacial-period slope-prograding strata on the lower continental slope. Seismic data give evidence of an associated debris-flow deposit embedded in the interglacial-period basin-fill strata of the basin floor. The total volume of sediment involved in the mass movement is about $20 \mathrm{~km}^{3}$. Indirect dating of the mass-wasting event, based on seismic-stratigraphic relationships of the slide scar and associated debris-flow deposit with underlying glacial-period slope units and the overlying interglacial-period basin-floor units, suggests that it took place at the transition between the last glacial period and the present-day interglacial. The initiation of the Gebra Slide is attributed to a combination of several factors, such as high sedimentation rates during the last glacial period, the unloading effect of a retreating ice sheet during deglaciation, pre-existing tectonic fabric and high seismicity in the area. This is the first recent submarine slide of this size identified on the glacial, continental margins of Antarctica. In morphology and general characteristics it is quite similar to the well-known large-scale submarine slides from the northern hemisphere glacial margins, although it is smaller. Its most striking characteristic is its lower-slope position (at 1500-2000 m of water depth), which remains up to now difficult to explain.
\end{abstract}

(C) 2002 Elsevier Science B.V. All rights reserved.

Keywords: Gebra Slide; Antarctic Peninsula; glacial continental margin; submarine slope stability; debris flow

\section{Introduction}

In recent years large-scale slope instabilities on continental margins have been the subject of many studies (Masson et al., 1998; Gardner et al., 1999; Laberg and Vorren, 2000a; Locat and

\footnotetext{
* Corresponding author.

E-mail address: yannick.imbo@rug.ac.be (Y. Imbo).
}

Lee, 2000; Weaver et al., 2000; Locat, 2001). Such instabilities seem to affect all types of submarine slopes although involving different types of mass-wasting processes and trigger mechanisms. Large-scale submarine slides are particularly well documented along the glacial continental margins of the North Atlantic: the Norwegian Sea (the Storegga Slide, the Trænadjupet Slide and the Andøya Slide), the Svalbard-Barents Sea (Bjørnøyrenna Slide and the Isfjorden Slide) 
and eastern Canada (the Verrill Canyon area and the northeast Newfoundland slope) (Bugge et al., 1987; Aksu and Hiscott, 1992; Piper et al., 1999; Laberg and Vorren, 2000a; Mosher et al., 1994; Mulder and Moran, 1995). The reasons for glacial margins to be highly unstable are numerous, but all are directly or indirectly related to the dynamics of the ice sheet: oversteepening of the margin by glacial-marine sedimentation processes, loading/unloading by a grounded ice sheet, glacio-eustatic sea-level variations, glacio-isostatic effects, seismicity, etc. (Bugge et al., 1987; Mosher et al., 1994; Mulder and Moran, 1995).

Also, the glacial margins of Antarctica are characterized by slope instabilities. Small-scale instabilities are quite common: smaller slumps and slides, mass gravity flows, turbidity currents and downslope meltwater processes through canyons have been reported by various authors (McGinnis and Hayes, 1995; McGinnis et al., 1997; Pudsey and Camerlenghi, 1998; Viseras and Maldonado, 1999; Nitsche et al., 2000; Escutia et al., 2000). However, large-scale instabilities and especially large submarine slides seem to be much more scarce than along the northern hemisphere glacial margins. The only well-documented example is that of the Crary Trough Mouth Fan in the Weddell Sea (Bart et al., 1999). The question thus rises whether this apparent scarcity of large-scale slides is due to the paucity of data from the Antarctic margins, or whether the glacial regime - and hence the factors determining slope instability in Antarctica is different from that of the North Atlantic.

In this paper we discuss the characteristics of a Late Quaternary large-scale submarine slide along the Trinity Peninsula Margin in the Central Bransfield Basin, Antarctic Peninsula: the Gebra Slide. This structure was discovered - and initially named the Gebra Valley - in 1993 during the GEBRA-93 research cruise (Canals et al., 1994; Gràcia et al., 1996) and investigated in more detail during the GEBRAP-96 cruise (Ercilla et al., 1998; Prieto et al., 1999). During the MAGIA-99 cruise, new swath-bathymetric and seismic data were collected in the area that provide detailed information about the morphology and the seismic-stratigraphic architecture of the slide.

\section{Regional setting: The Central Bransfield Basin}

\subsection{Geological setting and physiography}

The Bransfield Basin is a narrow, ENE-WSW elongated basin at the northern tip of the Antarctic Peninsula (Fig. 1). It is bounded by the South Shetland Islands to the north and by Trinity Peninsula to the south. The opening of the basin is estimated to have started between 4 and $1.3 \mathrm{Ma}$ ago (Barker, 1982; Larter and Barker, 1991). Structurally and morphologically, the Bransfield Basin is divided into three sub-basins: the Western, the Central and the Eastern Bransfield Basin, which are separated by the highs of Deception Island and Bridgeman Island, respectively. Here, we will focus on the Central Bransfield Basin.

The Central Bransfield Basin is about $230 \mathrm{~km}$ long and $125 \mathrm{~km}$ wide. It is an asymmetric basin, limited by a steep, rectilinear South Shetland Margin in the north and a gentle, undulating Trinity Peninsula Margin in the south (Gràcia et al., 1996). The Trinity Peninsula Margin has a total width of $80 \mathrm{~km}$ and includes an inner and an outer continental shelf, a slope and a continental rise that extends down to the basin floor (Figs. 1 and 2). The inner continental shelf is up to $250 \mathrm{~m}$ deep and incised by four large glacial troughs (Szeliga, 1990; Canals et al., 2002). Some shallower incisions can be recognized further to the NE, facing the Antarctic Sound, but their small dimensions suggest that they played only a minor role in the glacial drainage process and as a sediment pathway to the outer shelf. The troughs merge into the outer continental shelf, which varies in depth from about $900 \mathrm{~m}$ in the SW to only $500 \mathrm{~m}$ in the NE, facing the Antarctic Sound (Szeliga, 1990). The shelf edge forms a sinuous slope break characterized by three basinward-convex lobes that are the basinward prolongation of the main glacial troughs (Fig. 1). The continental slope is a steep (up to $20^{\circ}$ ) and essentially continuous feature locally incised by gullies (Ercilla et al., 1998). A $20-32 \mathrm{~km}$ wide, gently sloping continental rise separates the slope from the flat basin floor (Gràcia et al., 1997). The basin floor progressively deepens and widens towards the NE. In a discontinuous line from Deception 


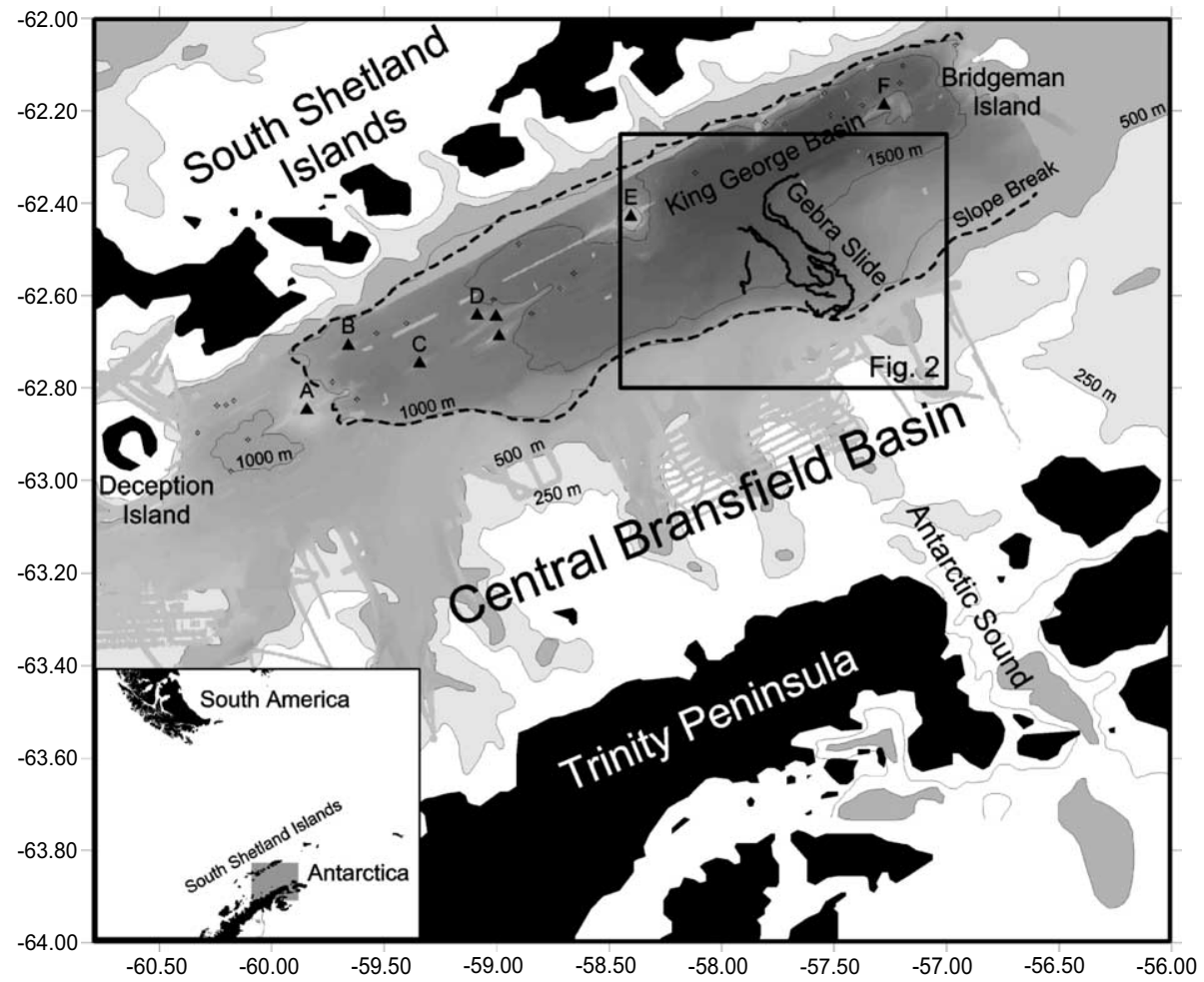

Fig. 1. Morphological map of the Central Bransfield Basin with the location of the glacial troughs on the upper shelf, the Gebra Slide on the Trinity Peninsula slope and the central King George Basin. A-F represent six large volcanic edifices (Gràcia et al., 1996). The general bathymetry in gray-scaling is based on a compilation of the GEBRA-93, GEBRAP-96 and MAGIA-99 multibeam data. The 250 and $500 \mathrm{~m}$ depth contours are from Szeliga (1990). Inset shows general location of the study area.

Island to Bridgeman Island six large volcanic edifices rise above the sedimented sea floor, where they depict an incipient sea-floor spreading ridge (Fig. 1; Gràcia et al., 1996). From SW to NE, four bathymetric levels can be distinguished, separated from each other by NW-SE morphological steps (Gràcia et al., 1996, 1997). The largest and the deepest of these levels constitutes the King George Basin, $20 \mathrm{~km}$ wide and $50 \mathrm{~km}$ long, with a maximum depth of $1950 \mathrm{~m}$ (Fig. 2).

\subsection{Seismic stratigraphy of the Central Bransfield Basin}

Two regional sedimentary sequences overlying the basement have been identified during previous seismic-stratigraphic studies (Gambôa and Maldonado, 1990; Jeffers and Anderson, 1990; Henriet et al., 1992; Prieto et al., 1998, 1999). A folded and faulted lower sequence reflects extensive tectonic activity during the opening and extension of the Bransfield Basin; it is hence often referred to as the 'rift sequence'. The overlying 'drift sequence' is characterized by only minor tectonic influences and by the presence of regional internal erosion surfaces, which find their origin in the cyclic, climatically driven advances and retreats of a grounded ice sheet. Based on these regional discontinuities, Prieto et al. (1999) distinguished eight seismic-stratigraphic units (U1-U8), the distribution of which is essentially controlled by the position of the ice sheet relative to the slope break throughout the glacial-interglacial cycles. During glacial periods, when the ice sheets are grounded all the way to the shelf edge, slope units (U1, U3, U5 and U7) composed of glacial diamictons are deposited on the Trinity Peninsula and South Shetland Islands' continental margins. 


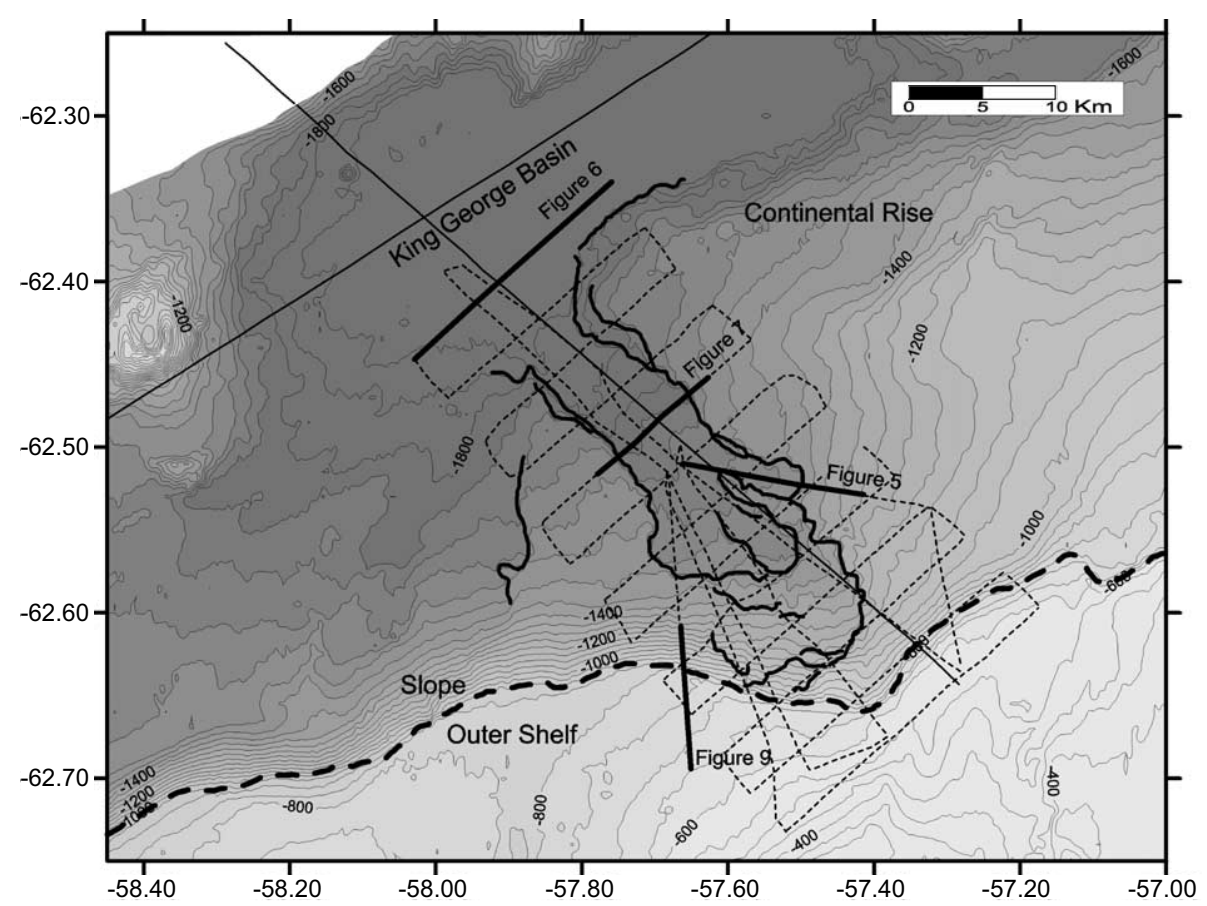

Fig. 2. Track plot of the seismic profiles recorded during the GEBRA-93 cruise (full lines) and the MAGIA-99 cruise (dashed lines). Profile segments shown in this paper are highlighted in bold. Bathymetry is derived from the GEBRA-93, GEBRAP-96 and MAGIA-99 multibeam data.

During 'interglacial' periods, when the grounding line of the ice sheets has retreated far up the shelf, sedimentation is restricted to hemipelagic deposition over the whole basin and to deposition of turbidites at the base of the continental slope and on the basin floor. During these periods, the basin-fill units (U2, U4, U6 and U8) are deposited, which are substantially thicker in the deeper part of the basin than on the slope and shelf.

\section{Methodology}

The majority of the seismic data used in this study has been acquired in 1999 during the MAGIA-99 expedition on board of $\mathrm{R} / \mathrm{V}$ Hesperides. This data set comprises a total of 22 high-resolution single-channel seismic profiles, with a combined length of $490 \mathrm{~km}$ (Fig. 2). It covers an area of $1015 \mathrm{~km}^{2}$ centered on the Gebra Slide and located between $57^{\circ} 10^{\prime}$ and $58^{\circ} 10^{\prime} \mathrm{W}$ and $62^{\circ} 20^{\prime}$ and $62^{\circ} 45^{\prime} \mathrm{S}$. All of the seismic data were shot with a sleeve-gun array of $4 \times 0.651$ as seismic source, and a three-channel SIG streamer of $150 \mathrm{~m}$ length as receiver. The data were recorded digitally with an ELICS DELPH-2 acquisition system. Post-acquisition data processing included band-pass filtering $(40-150 \mathrm{~Hz})$, spiking deconvolution and scaling, and was conducted on a Landmark ProMax processing system. The data have a theoretical vertical resolution of $8 \mathrm{~ms}$ (approximately $6 \mathrm{~m}$ ) and a penetration ranging from 200 ms two-way travel (TWT) on the shelf to $900 \mathrm{~ms}$ TWT in the deeper basin.

We also included two seismic lines that were acquired across the deep King George Basin during the previous GEBRA-93 expedition (GEBRA93 Lines \#5 and \#11) (Fig. 2). For these data, the seismic source was a 2.91 Bolt $1500 \mathrm{C}$ airgun, and the reflected signals were detected with a threechannel SIG-120 streamer. These data were also recorded digitally with an ELICS DELPH-2 system, and data processing (band-pass filtering, de- 

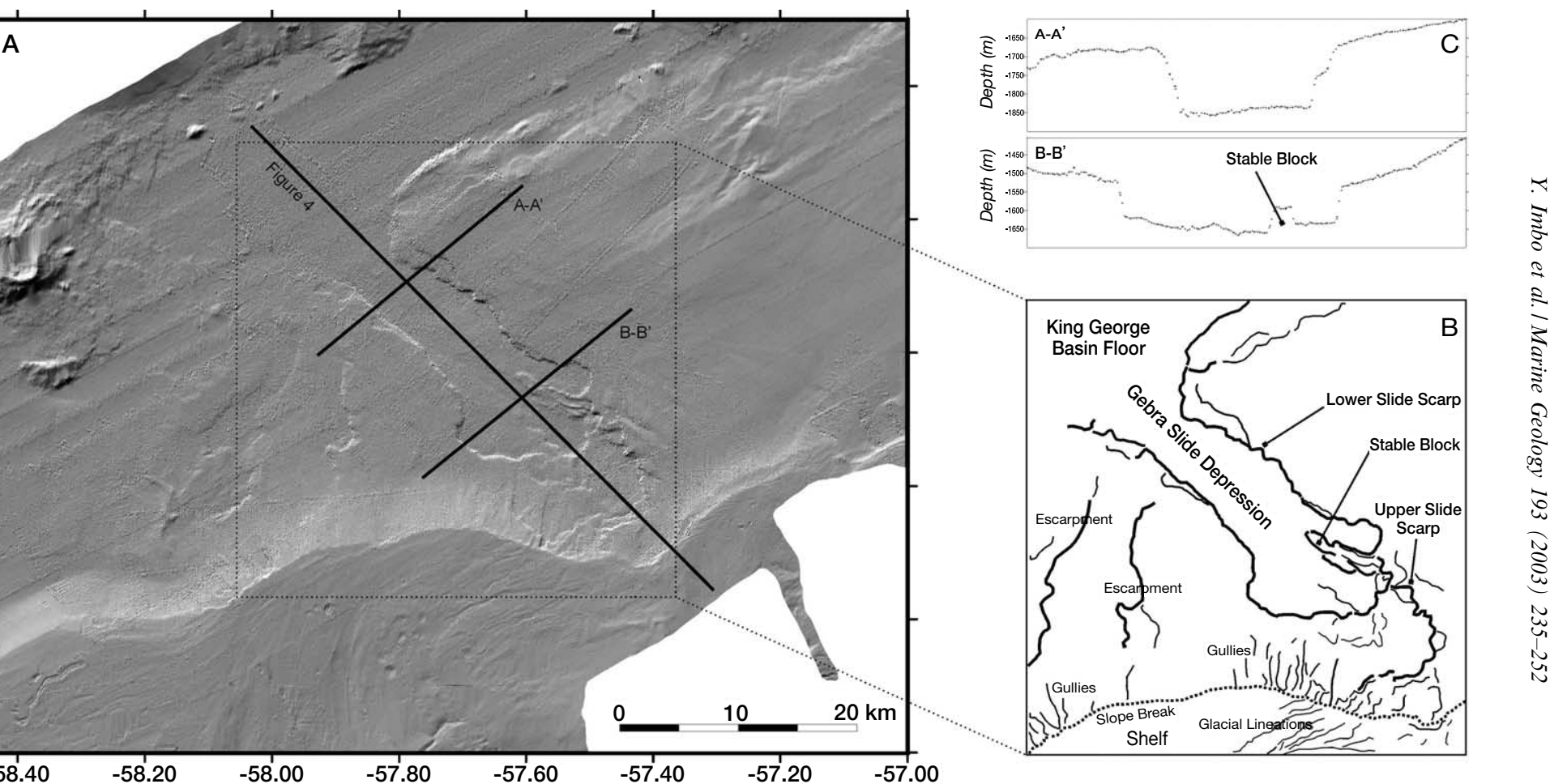

Fig. 3. (A) Shaded relief bathymetric map of the Central Bransfield Basin, with indication of cross-sections shown in panel C and Fig. 4. (B) Interpretative sketch of the Gebra Slide area with details, and annotation of the main features discussed in the text. (C) Bathymetric cross sections A- $\mathrm{A}^{\prime}$ and $\mathrm{B}-\mathrm{B}^{\prime}$ across the Gebra Slide, illustrating the typical morphology of the slide scar. 


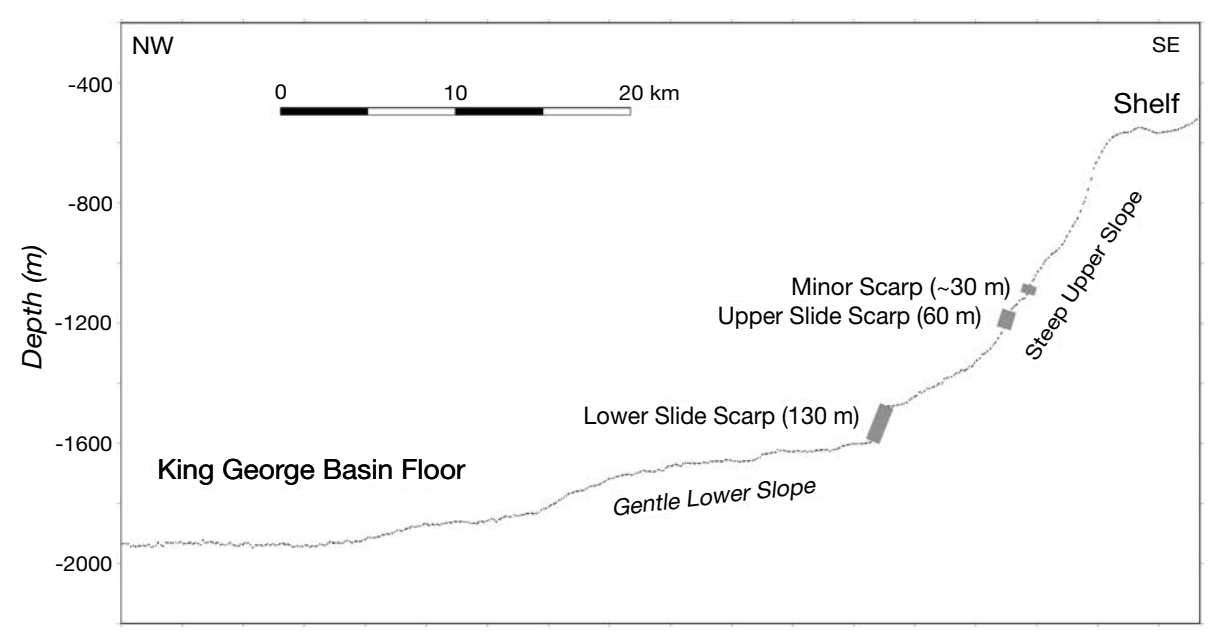

Fig. 4. Bathymetric cross section along the Gebra Slide, illustrating the morphology of the slide scar, the lower and upper head scarps, and the steep upper slope. Location of the cross-section is given in Fig. 3A.

convolution and scaling) was carried out both on the DELPH-2 system itself and on the SSL Phoenix Vector processing system.

The swath-bathymetry data were acquired during three successive expeditions in Bransfield Basin (GEBRA-93, GEBRAP-96, MAGIA-99), using the combined SIMRAD EM-12S/EM-1000 multi-beam system on board R/V Hesperides. Data processing of the individual data sets was done with the Mermaid and Neptune software packages. The three data sets were merged and data extraction was performed using an Irap GST option, so that each extracted point represents the mean value of all depth points in a grid of 75 by $75 \mathrm{~m}$. In this way, the bathymetry data used in this study are a synthesis of all currently available (Spanish) swath-bathymetric data in the Bransfield Basin.

\section{Description of the data}

\subsection{The Gebra Slide}

The swath-bathymetry data from the Central Bransfield Basin clearly reveal the presence of a major morphological feature on the continental slope of the northeastern part of the Trinity Peninsula Margin, situated between 1500 and $1950 \mathrm{~m}$ of water depth and at about $57^{\circ} 40^{\prime} \mathrm{W}$ and $62^{\circ} 30^{\prime} \mathrm{S}$
(Figs. 3 and 4) (Canals et al., 1994; Gràcia et al., 1996). The shape, position and overall aspect of the feature - on bathymetry data as well as on seismic profiles - suggest that it represents a large slide scar, very similar to submarine slide scars observed on other glacial continental margins, such as the Storegga Slide (Bugge et al., 1987), the Trænadjupet Slide (Laberg and Vorren, 2000a) and the Andøya Slide (Laberg et al., 2000).

The Gebra Slide scar has a cauliflower-like shape with well-exposed scarps. It is about 30 $\mathrm{km}$ in length and $5-12 \mathrm{~km}$ wide (Fig. 3). It has a distinct U-shape in cross-section: the floor of the slide scar is flat, while the sidewalls are extremely steep with a mean gradient of $17^{\circ}$ and a maximum incision of $230 \mathrm{~ms}$ TWT (about $175 \mathrm{~m}$ ) (Fig. 3C). The head of the slide scar is formed by an amphitheatre-shaped scarp with an elevation of $130 \mathrm{~ms}$ TWT (about $100 \mathrm{~m}$ ) and a gradient of $16^{\circ}$ (Fig. 4). The entire slide scar area, bounded by these clearly defined head- and sidewalls, amounts to about $160 \mathrm{~km}^{2}$.

Further upslope from this slide scar, a second scarp is visible in water depths of $1000-1500 \mathrm{~m}$ (Figs. 3 and 4). This secondary, less well-developed scarp gradually disappears upslope towards the southwest, where it approaches but not completely reaches the shelf edge. The slide-scar area bounded by this secondary headwall is about 70 
$\mathrm{km}^{2}$, which brings the total surface affected by the Gebra Slide to $230 \mathrm{~km}^{2}$.

The Gebra Slide is located at the transition between two distinct morphostructural segments of the Trinity Peninsula Margin, and in between two of the basinward-convex lobes that mark the shelf edge (Fig. 3) (Prieto et al., 1999; Canals et al., 2002). To the northeast of the Gebra Slide the margin consists of a gentle, uniform slope with a mean gradient of about $1^{\circ}$ and underlain by an up to $600 \mathrm{~m}$ thick sedimentary sequence (Fig. 5). In the upper part of this sequence, the strata are characterized by a discontinuous wavy pattern, which may be either the acoustic expression of creep folds announcing further failure of the margin (Mulder and Cochonat, 1996) or of sediment waves indicative of bottom-current activity (Ercilla et al., 1998; Howe et al., 1998; Faugères et al., 2002). Southwest of the Gebra Slide, the margin changes to a slope with a steeper, ex- ponential curvature, with a maximum gradient of about $20^{\circ}$. Here, mass-wasting is apparent on the seismic data from a number of slid blocks on the lower slope, and on the bathymetry data from several 10-15 km long gullies incised in the slope strata. These gullies have a U-shaped cross-section, and reach widths of up to $2 \mathrm{~km}$ and depths of up to $40 \mathrm{~m}$.

At the downslope end of the Gebra Slide scar, the basin floor of the King George Basin is completely smooth and flat at a depth of $1950 \mathrm{~m}$; there is no sign in the bathymetry data of any depositional mound related to the Gebra masswasting event (Fig. 3). The seismic data, however, reveal the presence of a large, well-defined sedimentary unit - up to about $100 \mathrm{~m}$ (135 ms TWT) thick - completely covered by another $100 \mathrm{~m}$ of the youngest basin-fill unit U8 (Fig. 6). Its seismic facies is characterized by a reflection-free to chaotic, irregular, low-amplitude pattern, and a high-
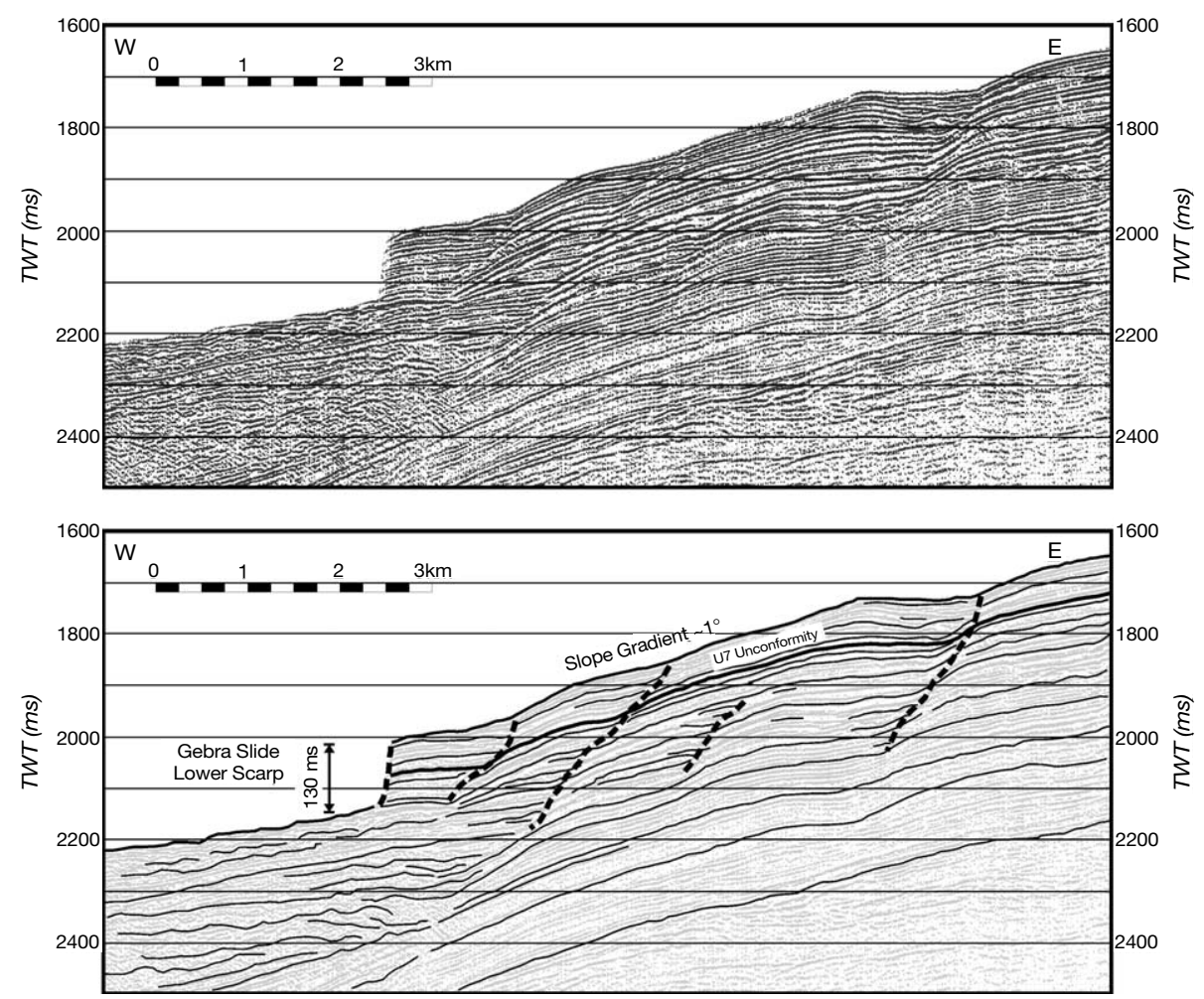

Fig. 5. Seismic airgun profile and interpreted line drawing of MAGIA-99 line \#37, illustrating the wavy pattern in the sedimentary section to the east of the Gebra Slide. The unconformity at the base of unit U7 is cut by the Gebra Slide scarp. Location of the seismic line is given in Fig. 2. 

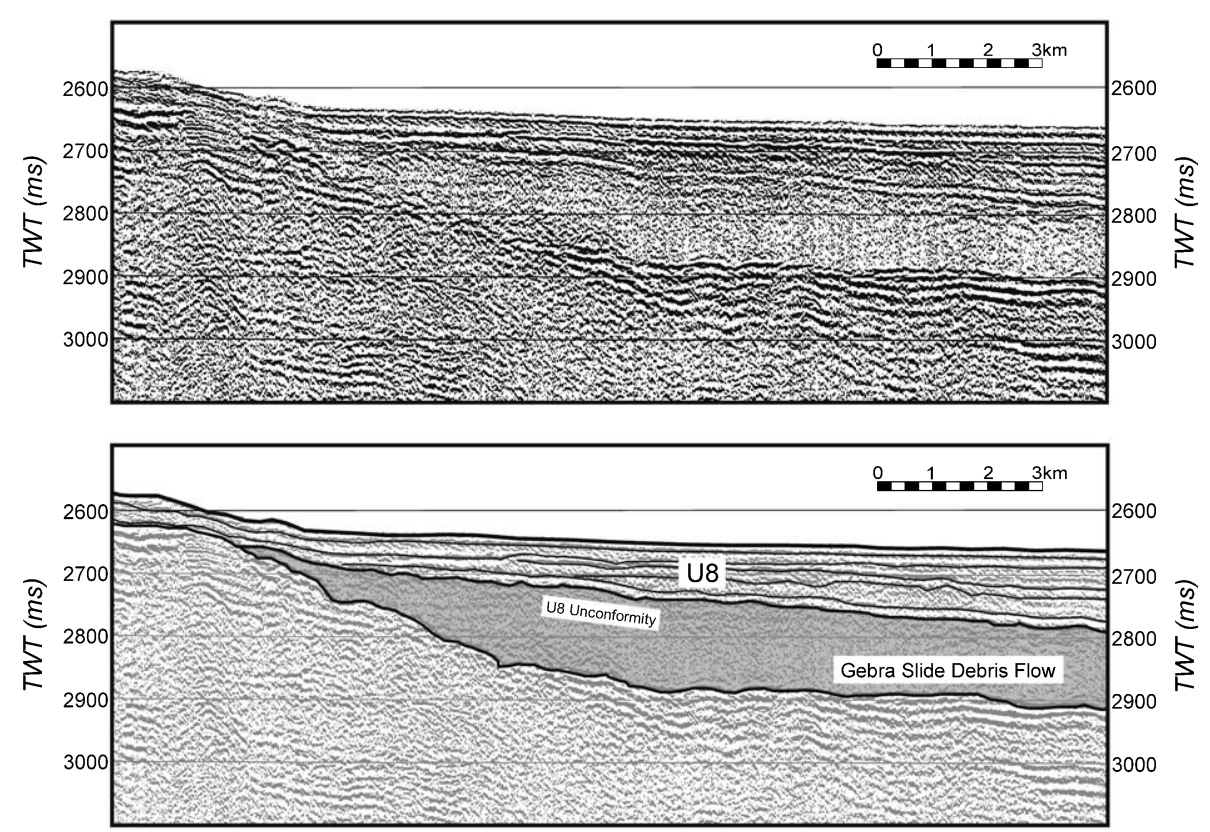

Fig. 6. Seismic airgun profile and interpreted line drawing of MAGIA-99 \#55. The Gebra Slide debris-flow deposit fills the central King George Basin, and is completely covered by unit U8. Location of the seismic line is given in Fig. 2.

amplitude reflector often marks its base. This facies is typical for debris-flow deposits and clearly contrasts with the horizontally stratified, high-amplitude facies with continuous reflectors characteristic of unit U8 (Fig. 6). This mostly transparent facies unit fills in the western part of the King George Basin and pinches out against the lower slopes of volcanic edifices $F$ in the east and $D$ in the west, against the foot of the South Shetland Islands Margin in the north and against the foot of the Trinity Peninsula Margin in the south, at about $2500 \mathrm{~ms}$ TWT water depth near the downslope limit of the Gebra Slide scar (Figs. 7 and 8) It covers a total surface of about $280 \mathrm{~km}^{2}$. Upslope from there, transverse seismic profiles MAGIA-99 \#34 and MAGIA-99 \#36 reveal a second small isolated lens of the debris-flow deposit, characterized by its typical chaotic seismic facies, within the confines of the main slide scar, near the main scarp at a depth of $1500 \mathrm{~m}$ (Fig. 8).

\subsection{Recent seismic stratigraphy in the Gebra Slide area}

The Gebra Slide and its associated debris flow affect the uppermost slope unit U7 and basinal unit U8 of the seismic-stratigrafic model of Prieto et al. (1999). Slope unit U7 covers the Trinity Peninsula slope and shelf in the vicinity of the Gebra Slide. The unit is characterized by a progradational stratified seismic facies with high-angle dipping reflections that downlap onto the underlying units (Fig. 9). The upper boundary of this unit is formed by an erosional unconformity at the upper-slope platform, which changes to a conformable surface in the basinward direction and reflects the end of the last major expansion of the ice sheets. The unit pinches out in the basinward direction near the foot of the slope. The main depocenter of unit U7 is located under the outer shelf to the northeast of the Gebra Slide scar (190 ms TWT). Downslope from the Gebra Slide, the King George Basin is filled by basinal unit U8 (Prieto et al., 1999) (Fig. 6). This unit is characterized by a horizontally stratified, highamplitude facies with continuous reflections. The base of this unit is a conformable surface, highlighted by a group of reflections with even higher amplitudes. Unit U8 covers the basin floor, the slope and the outer shelf. It thus overlies the Ge- 


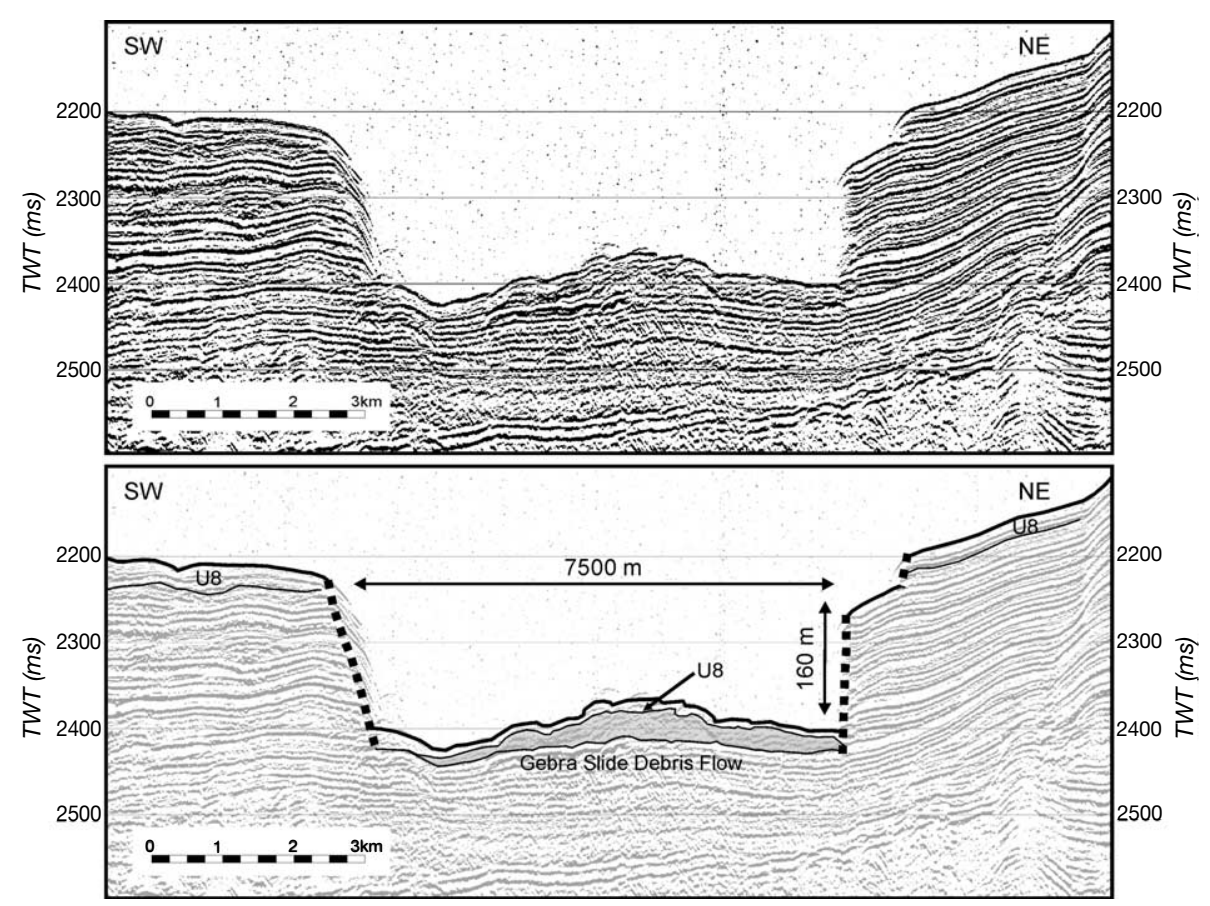

Fig. 7. Seismic airgun profile and interpreted line drawing of MAGIA-99 \#51. A debris-flow deposit covers the basin floor of the steep-sided Gebra Slide scar. Location of the seismic line is given in Fig. 2.

bra Slide debris flow in the basin and slope unit U7 on the slope and shelf. It has an overall lensshape, with the thickest part following the basin axis, and expresses the infill of the basin by glacial-marine sedimentation processes since the retreat of the ice sheets.

\section{A multi-phase instability event?}

From the above-presented data, it is evident that the Gebra slide scar and the large debrisflow deposit downslope from it, both result from the same slope failure (Fig. 7). Due to the lack of cores and precise age information, it is difficult to tell whether this slope failure occurred as one single event or whether it has a multi-phase character. The multibeam data and the seismic profiles provide indications that the slope failure affected sediments at different depths in different parts of the slide.

- Firstly, the swath-bathymetry data clearly show two groups of slide scars: a main slide scar between 1500 and $2000 \mathrm{~m}$, and a second, less pronounced slide scar higher up the slope from the first one, between 1000 and $1500 \mathrm{~m}$ (Figs. 3 and 8).

- Secondly, the seismic data show two separate debris-flow units (Fig. 8). The main debris-flow deposit extends across most of the King George Basin, and pinches out towards the foot of the Trinity Peninsula slope near the downslope end of the slide scar. Upslope from there, the second, smaller and isolated debris-flow deposit is confined to the floor of the main slide scar. The two debris-flow units are not attached, although they share the same basal horizon.

The hypothesis of a first massive slide event followed by a smaller second one is supported by a quick, rough mass-balance exercise. In a first phase, the lower slope of the Trinity Peninsula Margin collapsed over an area of $160 \mathrm{~km}^{2}$. The total volume of sediment that was involved in this first slide is on the order of $20 \mathrm{~km}^{3}$, assuming an average thickness for the removed slice of $160 \mathrm{~ms}$ TWT (about $120 \mathrm{~m}$ ) as suggested by our seismic data. Once moving, the slid mass probably rapidly 


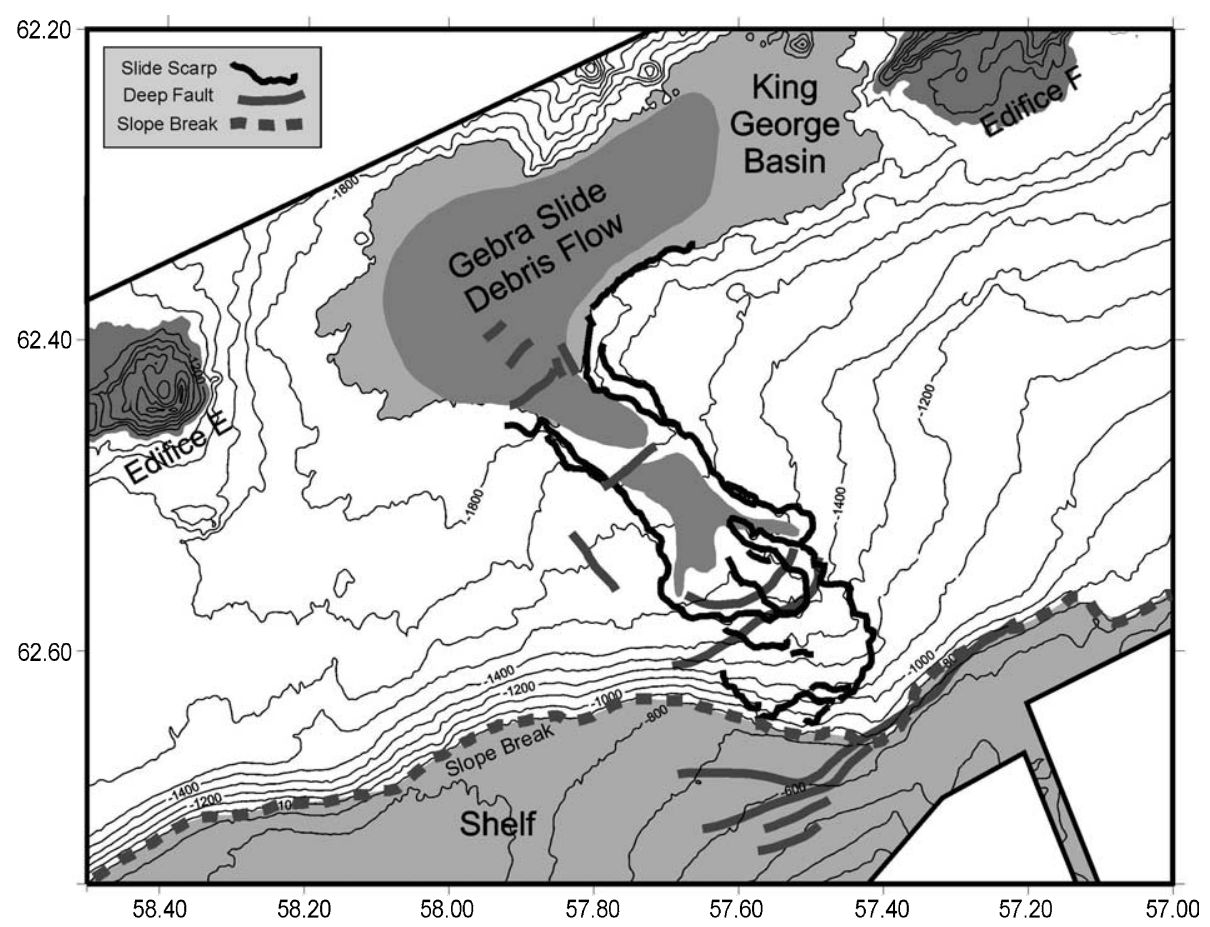

Fig. 8. Interpretative sketch of the Gebra Slide scar with its side and head scarps in a cauliflower-like geometry and two separated debris-flow deposits: a large buried deposit in the King George Basin, and a smaller one within the confines of the slide scar. Two basement faults coincide with the main lower head scarp and the Trinity Peninsula shelf break, respectively. The Gebra Slide area is located at the transition of two morphologically different domains: to the east, the margin shows a uniform, gentle slope, while to the west the margin shows an exponential curvature.

disintegrated and evolved into a debris flow, which spread out across the flat King George Basin, over an area of $280 \mathrm{~km}^{2}$. The total volume of the debris-flow deposit is about $21 \mathrm{~km}^{3}$, assuming an average thickness of $100 \mathrm{~ms}$ TWT (about $75 \mathrm{~m}$ ). This implies that the main debris-flow deposit is already fully accounted for in volume by the primary slide scar and by this first phase of mass wasting. Subsequently, during a separate phase or in a more or less continuous succession of events, the upper slope of the margin destabilized, presumably due to the loss of bearing capacity of the collapsed lower slope. The total area affected by this secondary slide is only about 70 $\mathrm{km}^{2}$. The resulting debris flow was channeled within the depression of the primary scar and was deposited on the flat floor of the scar on the lower slope over an area of about $35 \mathrm{~km}^{2}$ (Fig. 8). Given the limited thickness of this second debris-flow unit, its volume is negligible and comparable to that of the sediment slice removed from the upper slope in the second slide.

It is not uncommon for a large-scale submarine slide to occur in several, consecutive phases. The Verrill Canyon area on the Scotian Slope and successive landslides in the Canary Islands illustrate such multi-phase mass-wasting processes (Mosher et al., 1994; Masson et al., 1998; Gee et al., 2001). The Humboldt Slide, on the northern California continental margin, is interpreted as a large shear-dominated retrogressive slope failure (Gardner et al., 1999). During the last glacial, the Svalbard-Barents Sea Margin was highly instable and generated successive slope failures with a frequency varying between 95 and $170 \mathrm{yr}$ (Dimakis et al., 2000). Also, the Trænadjupet Slide, off the coast of Norway, consists of two escarpments and is possibly the product of a progressive 

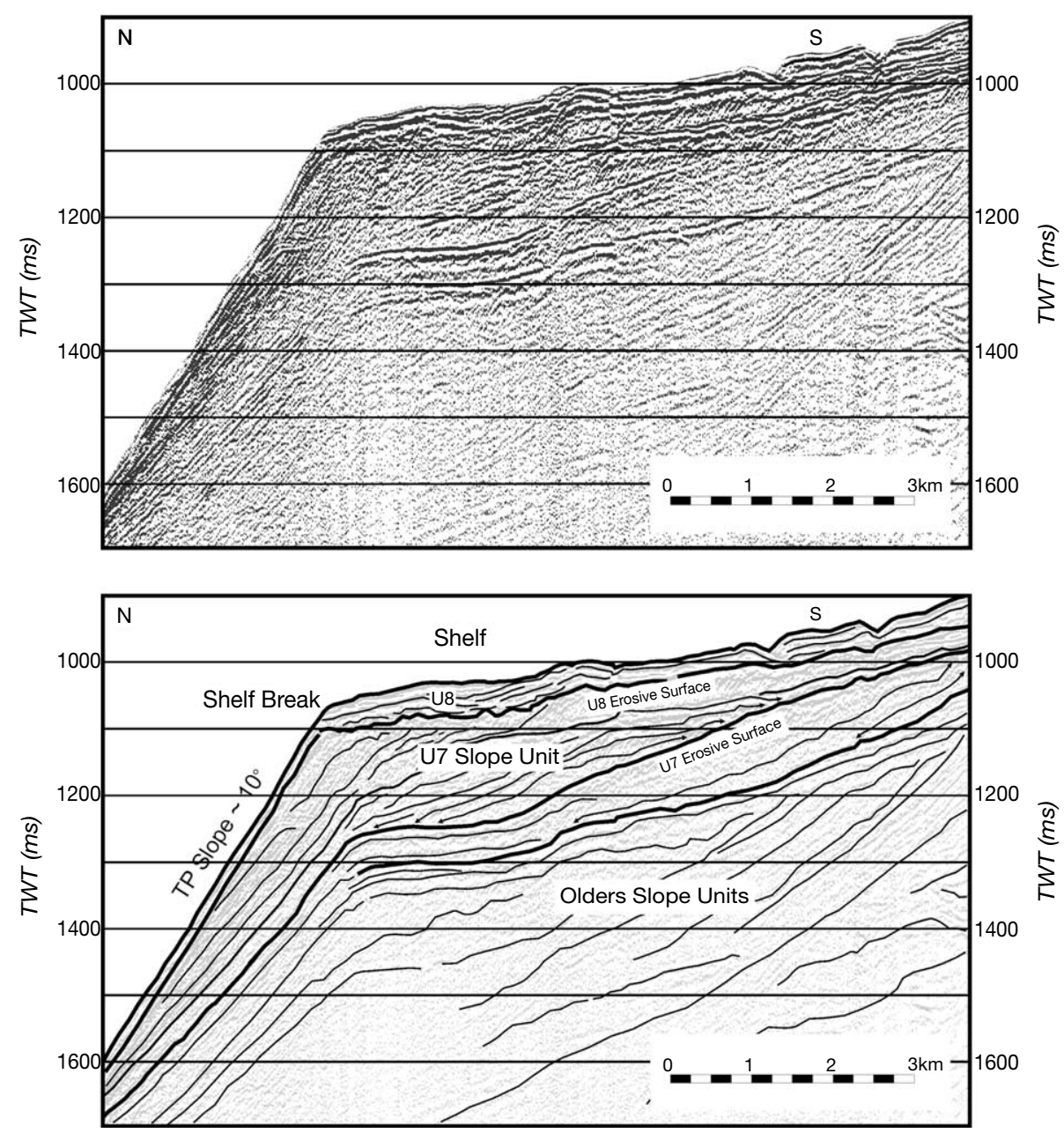

Fig. 9. Seismic airgun profile and interpreted line drawing of MAGIA-99 \#33. The shelf is composed of a stacked pattern of slope units deposited during periods of maximum expansion of the ice sheets. On top, interglacial unit U8 drapes unit U7. Location of the seismic line is given in Fig. 2.

backstepping of the slide upslope due to the loss of support from the removed sediments (Laberg et al., 2002a,b).

However, it should be noted that similar morphologies may also be generated during a single event, as was the case for the 1929 earthquaketriggered Grand Banks Slide (Piper et al., 1999).

\section{Age of the Gebra Slide}

In the absence of deep cores from the slide scar or associated deposit, the age of the Gebra Slide can only be derived indirectly, e.g. from seismicstratigraphic analysis. There are some observations and lines of reasoning that can help to narrow down the potential time window:

- The seismic data show clearly that the main slide scar is cut into the distal toes of seismicstratigraphic slope unit U7. This implies that the slide must have taken place during or after deposition of $\mathrm{U} 7$, so during or after the last glacial period in the area (Fig. 5).

- The freshness of the morphology of the slide scars on the swath-bathymetry data and on ultrahigh-resolution sub-bottom profiles indicates that 


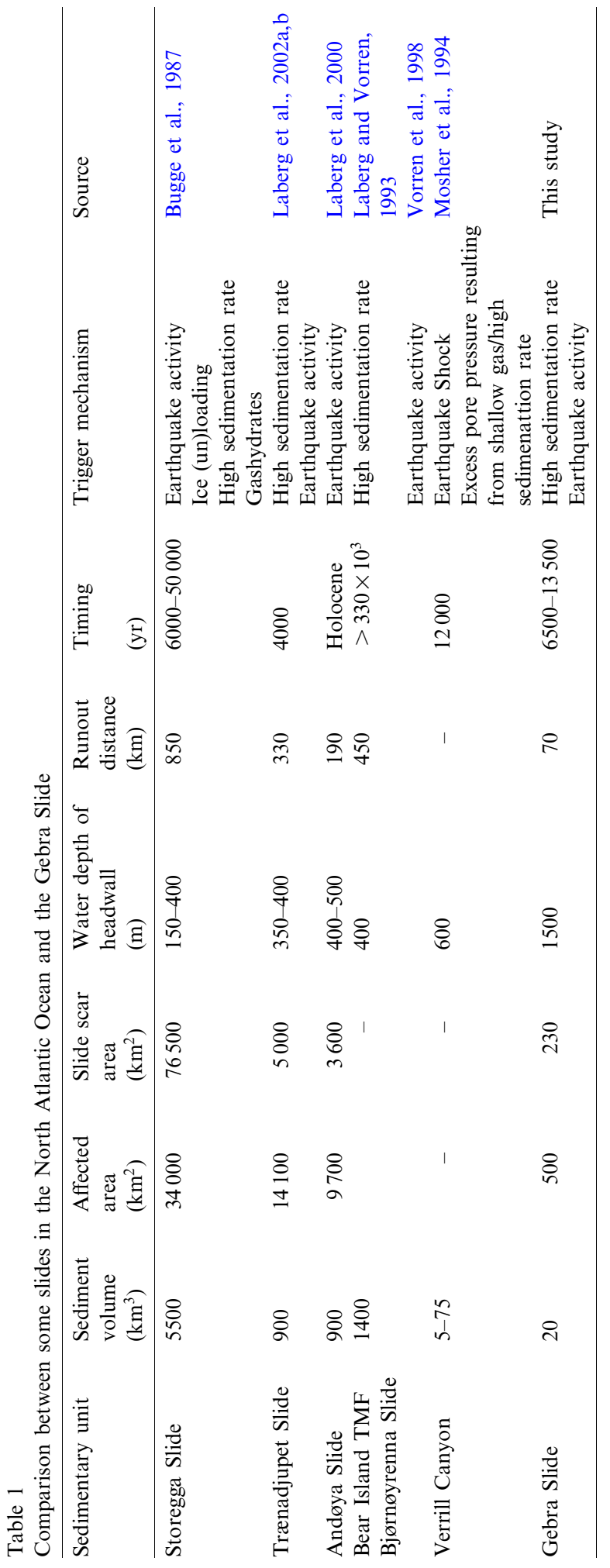

the Gebra Slide has not been covered by or buried under a significant amount of post-slide slope strata, i.e. post-slide glacial-period strata (Fig. 7). This observation implies that the slide must have taken place at the very end of or after the last glacial period.

- The seismic data also illustrate that the debris-flow deposits attributed to the Gebra Slide are totally covered by seismic-stratigraphic basin-fill unit U8 (Figs. 6 and 7). According to Prieto et al. (1999), this basin-fill unit U8 is formed during the present-day interglacial period. As the debris-flow deposits occur just below the base of unit U8, this means that the slide must have taken place at the very beginning of the last interglacial period in the area.

Our data thus indicate that the Gebra slope instability event took place around the transition between the last glacial period and the current interglacial period. According to Banfield and Anderson (1995), the ice sheet retreated from the Central Bransfield Basin outer shelf at around 13500-14500 yr BP. According to Pudsey et al. (1994), open marine sedimentation started shortly before $11000 \mathrm{yr} \mathrm{BP}$ on the outer shelf off Anvers Island, to the southwest of the Bransfield Basin. The shallower and largely sediment-free inner shelf cleared much later, perhaps around $6000 \mathrm{yr}$ BP (Canals et al., 2002). On our seismic data, the most recent seismic-stratigraphic interglacial unit U8 is essentially developed on the King George basin floor (over $100 \mathrm{~m}$ of thickness), but it also extends, although much thinner (only about $7 \mathrm{~m}$ ), on the slope and outer shelf of the Trinity Peninsula Margin (Figs. 6 and 7). The difference in thickness between the basin-floor setting and the slope and shelf setting is attributed to a difference in the predominant sedimentation process: mainly hemipelagites on the outer shelf, and a mixture of hemipelagites, turbidites and small-scale masswasting deposits on the basin floor. Based on a piston core, collected at a water depth of $550 \mathrm{~m}$ from the upper slope of the central basin (adjacent to King George Basin), Harden et al. (1992) report a minimum sediment accumulation rate for the lower part of that core of $0.49 \mathrm{~cm} / \mathrm{yr}$ on a $1000 \mathrm{yr}$ time scale. The upper portion of the core corresponds to a slower accumulation rate 
of $0.12 \mathrm{~cm} / \mathrm{yr}$. Applied to an assumed open marine sedimentation starting at 13500-14500 yr BP in the Bransfield Basin (Banfield and Anderson, 1995), this yields a sediment drape of 15-70 m, which is in the range of our observations on seismic profiles from similar water depths and environments. This corresponds quite well with the observations of Canals et al. (2000), who report, based on the analysis of ultra-high-resolution subbottom profiles, a 7-75 m thick Holocene drape of mixed hemipelagites, turbidites and mass-wasting deposits on top of a 'bundle structure' representing the last major expansion of the ice sheet. Such high interglacial sedimentation rates in the deeper parts of Bransfield Basin, and in King George Basin especially, are caused by the relatively moderate climate (Harden et al., 1992) and the enclosed geography of the King George Basin that acts as a sediment trap. A similar situation occurs in Palmer Deep, a structurally controlled depression in the continental shelf of the Northern Antartic Peninsula off Anvers Island, where a hemipelagic infill of $45 \mathrm{~m}$ has accumulated during the Holocene (Brachfeld et al., 2002). It is evident that the average sediment accumulation rates on the open Antarctic shelves - outside such isolated depressions - are much lower: e.g. on the shelf of Marguerite Bay the sedimentation rate drops to 0.02-0.05 cm/yr (Harden et al., 1992).

An early interglacial age (i.e. transition from glacial to interglacial period) for the Gebra slope collapse agrees with several other studies of largescale submarine slope instabilities along glaciated margins. While the build-up of the slope-prograding glacial strata is generally attributed to sustained, but relatively small-scale debris-flow activity from the ice-sheet grounding line during glacial periods (e.g. Alley et al., 1989; Aksu and Hiscott, 1992; Laberg and Vorren, 1995, 2000b), the larger-scale, more catastrophic failure of these glacial strata is usually believed to occur in a later phase, after deglaciation and during the interglacial periods (Bugge et al., 1987; Bart et al., 1999; Laberg and Vorren, 2000a). Based on analyses of maximum ice-loading events for the Scotian slope, Mulder and Moran (1995) suggest that the change in ice loading (e.g. during retreat of the ice sheets) rather than high sedimentation rates, is the dom- inant mechanism for large-scale instability events on glacial margins.

\section{Factors promoting failure}

Various potential controlling factors have been proposed to explain the occurrence of large-scale slope instabilities along continental margins: (1) build-up of excess pore pressure due to high sedimentation rates; (2) loading by a static weight (i.e. the loading of a grounded ice sheet); (3) seepage of shallow methane gases or destabilization of gas hydrates; (4) oversteepening of the margin; (5) erosion at the toe of the slope; (6) tectonic setting; and (7) earthquakes (Bugge et al., 1987; Mosher et al., 1994; Mulder and Moran, 1995; Dimakis et al., 2000; Laberg and Vorren, 2000a). Below, we will tentatively evaluate the potential of each of these controlling factors for having triggered the Gebra Slide.

\subsection{Build-up of excess pore pressure due to high sedimentation rates}

Probably the main cause of submarine sliding along continental margins is the build-up of excess pore pressure in fine-grained sediments as a result of rapid sedimentation. Upper continental slopes in high latitudes are often characterized by very high sedimentation rates, particularly during glacial periods in the ice-proximal zones, i.e. with the development of trough-mouth fans (Vorren and Laberg, 1997). Recent studies on the Bear Island Fan (NE North Atlantic) yielded sediment accumulation rates of up to $60 \mathrm{~cm} / \mathrm{yr}$ within a $5 \mathrm{~km}$ wide ice-proximal zone during the last glacial period (Laberg and Vorren, 1995; Dowdeswell and Siegert, 1999; Dimakis et al., 2000). As a consequence of this extremely rapid loading, the Bear Island Fan underwent severe slope failure (note that these failures occurred during glacial times, in contrast to those of the Gebra Slide). Sedimentation rates in the Bransfield Basin have most likely been much smaller and therefore most likely not sufficient to build up a significant excess in pore pressure within these deposits and to generate the observed large-scale slope failure (Dima- 
kis et al., 2000). It is, however, not excluded that locally, e.g. in the vicinity of the grounding line at the mouth of a glacial trough and for short periods of time, sedimentation rates were temporarily higher than the above average, which could have generated high pore pressures in a thin slice of sediments. This process could easily have led to small-scale mass wasting (Elverhøi et al., 1997; Dowdeswell and Siegert, 1999), and could thus explain the presence of the numerous thin debris-flow-like lenses that are incorporated in the strata at the foot of the steep upper slope.

\subsection{Loading/unloading by an advancing/retreating grounded ice sheet}

Our data clearly show that the main Gebra Slide occurred at a water depth of 1500-2000 m, affecting only the distal toes of the glacial-period prograding-slope strata. This is far below the maximum grounding depth of the ice sheets during glacial periods. For example, Canals et al. (2000) inferred a maximum grounding depth of $900 \mathrm{~m}$ (present-day water depth) for a $1 \mathrm{~km}$ thick ice sheet during the Last Glacial Maximum in the Western Bransfield Basin, which is in agreement with earlier estimates of Banfield and Anderson (1995). Although we are aware that ice-sheet loading on a continental shelf may induce far-field pore-pressure effects (Mulder and Moran, 1995), we believe that such loading/unloading effects should primarily have had an impact on the steeper, thicker - and thus more rapidly accumulated and inherently more unstable - upper-slope deposits, closer to the grounding zone.

\subsection{Destabilization of gas hydrates or seepage of shallow methane gases}

Bottom-simulating reflectors indicative of the presence of gas hydrates have been reported from the Pacific Margin of the South Shetland Islands (Lodolo et al., 1993), but not from within the Central Bransfield Basin despite the very extensive seismic coverage. Also, none of the available swath-bathymetry and seismic data from the Trinity Peninsula Margin show traces of pockmarks, acoustic blanking, acoustic wipe-out zones, enhanced reflectors or velocity pull-downs that could indicate the presence of shallow gas. However, on some of the seismic data from the basinfloor parts of Bransfield Basin some indications can be seen for gas or fluid accumulations or migration in the vicinity of the volcanic edifices, but these sites are a few tens of $\mathrm{km}$ away from the Gebra Slide.

\subsection{Oversteepening of the margin}

The swath-bathymetry and seismic data show that the Gebra Slide affected essentially the lowest and least steep part of the slope (average slope of less than $1^{\circ}$ ), while the higher parts of the margin, which are steeper (average slope of $7-8^{\circ}$ ) and have accumulated more sediment, were only involved in the second phase of sliding, or remained entirely intact. Upslope the Gebra Slide, the steepest part of the Trinity Peninsula slope is characterized by gradients of up to $20^{\circ}$. Such an exponential slope curvature is distinctive for a glacial sedimentation environment with an ice sheet overstepping the slope break during glacial periods.

\subsection{Erosion at the toe of the slope}

There are no indications for erosion - e.g. by contour currents - at the foot of the Trinity Peninsula slope within the Central Bransfield Basin, which would be an additional factor of oversteepening.

\subsection{Tectonic setting}

Gebra Slide is located at the transition between two morphostructural segments of the Trinity Peninsula Margin. The distinct morphological changes across this boundary (difference in margin orientation, slope angle and stratigraphic architecture) are sometimes attributed to a first-order tectonic segmentation of the entire Bransfield Basin (see also Barker and Austin, 1998). Surprisingly, on our seismic data, which do penetrate to the top of the basement, no trace of marginperpendicular faults can be observed. We do, however, observe a number of other faults that are generally oriented parallel to the margin, 
with the downthrown side towards the basin (Prieto et al., 1998) (Fig. 8). These faults do not affect the sedimentary cover. Nevertheless, the position of the main headwall of the Gebra Slide coincides exactly with one of these faults. In fact, also the position of the shelf break coincides with one of these margin-parallel faults, which suggests that - in one way or another - these basement structures still influence the presentday morphology.

\subsection{Earthquakes}

The Central Bransfield Basin is a seismically highly active area (Pelayo and Wiens, 1989; Ibañez et al., 1997). Recent seismic and volcanic activity in the basin is concentrated along the central volcanic lineament, and especially at the six large submarine volcanic edifices, at Deception Island and at Bridgeman Island. The latter has been the epicenter of many recent earthquakes with a magnitude of up to $M=6.7$ (Jin et al., 1998). The Gebra Slide is located within a radius of less than $30 \mathrm{~km}$ from this central lineament, less than $40 \mathrm{~km}$ from the nearest seamount, and only at $80 \mathrm{~km}$ from Bridgeman Island.

In addition to their seismic activity, the submarine volcanic edifices appear to be responsible for the enrichment of clay minerals $(58 \%$ illite, $19 \%$ chlorite and $19 \%$ smectite for the $<2 \mu \mathrm{m}$ clay minerals) in the Central Bransfield Basin (Yoon et al., 1994). We cannot rule out that certain stratigraphic levels associated with strongly increased volcanic activity can be characterized by high amounts of volcanically derived clay minerals and zeolites, which could develop into potential slip planes for both small-scale and large-scale mass-wasting events.

The most likely trigger mechanism is probably one involving a combination of various factors. While high sedimentation rates during the last glacial period and the unloading effect by the retreating ice sheet during deglaciation may have induced higher-than-normal pore pressures in the Trinity Margin deposits and rendered them prone to failure, additional triggers - such as tectonic fabric and earthquakes - were probably re- quired to destabilize them and initiate the Gebra collapse.

\section{Comparison with other high-latitude large-scale submarine slides}

The Gebra Slide - as documented here by swath-bathymetry and reflection seismic data is so far one of the few known large-scale submarine slides along the entire Antarctic Margin. In contrast, the northern hemisphere glacial margins appear to be scarred by many more of such largescale slope instabilities. In Table 1 Gebra Slide is compared to the most significant (i.e. best documented) Late Quaternary slides along the North Atlantic margins. Although Gebra Slide affects an area of more than $500 \mathrm{~km}^{2}$ (slide scar and associated deposit combined), it is quite small in comparison with most of its North Atlantic counterparts, such as the Storegga Slide, the Trænadjupet Slide and the Andøya Slide with affected areas of $34000 \mathrm{~km}^{2}, 14100 \mathrm{~km}^{2}$ and $9700 \mathrm{~km}^{2}$, respectively. What it does have in common with most of the northern slides is a Holocene age of triggering. The most remarkable difference, however, is the water depth at which they occurred. All quoted North Atlantic slides are located at water depths that do not exceed $600 \mathrm{~m}$, while the Gebra Slide is located at $1500 \mathrm{~m}$ of water depth, on the lower slope of the margin. One reason for this could be the higher seismic activity of Bransfield Basin compared to the passive North Atlantic margins. The occurrence of slides in deeper water is, however, not really uncommon. Several smaller slides in the North Atlantic region also occur at larger water depths (e.g. Hughes Clarke et al., 1992; Savoye et al., 1990). At present, we cannot explain the cause of such deep-water large-scale instabilities, as they seem to be in contradiction to the most common trigger mechanisms for sliding (i.e. high sedimentation rates, loading by ice sheets, oversteepening,...). It would be very useful to continue to map the Antarctic margins, using state-of-the-art and fast methods such as swath-bathymetry, in order to locate and investigate other slope-instability features and to verify 
whether a lower-slope position is a common attribute for Antarctic submarine slides.

\section{Conclusions}

- A large submarine slide - the Gebra Slide has been imaged on the continental margin of Trinity Peninsula, Central Bransfield Basin, Antarctic Peninsula. The slide scar is clearly expressed in the bathymetry $(30 \mathrm{~km}$ long, $6 \mathrm{~km}$ wide, maximum $175 \mathrm{~m}$ deep) and is cut into the toes of the glacial-period slope-prograding strata on the lower slope, at 1500-1950 m of water depth. A second, less-developed scar occurs further upslope, at a depth of $1000-1500 \mathrm{~m}$. The total affected area is about $230 \mathrm{~km}^{2}$. The associated deposit is a debris flow (maximum thickness $100 \mathrm{~m}$ ) embedded into the interglacial-period basin-fill strata of the King George Basin. It extends over a total surface of about $280 \mathrm{~km}^{2}$. The total volume of sediment involved in the mass movement is about $20 \mathrm{~km}^{3}$.

- Indirect dating of the mass-wasting event, using seismic-stratigraphic criteria, suggests that it took place at the transition between the last glacial period that affected the area and the presentday interglacial (between 13500 and $6500 \mathrm{yr}$ BP).

- It is difficult to define the trigger mechanism responsible for the initiation of the Gebra Slide. High sedimentation rates during the last glacial period or the presence of a clay-rich, cohesive ash layer together with the unloading effect by the retreating ice sheet during deglaciation may have induced higher-than-normal pore pressures in the Trinity Margin deposits and rendered them prone to failure. However, additional triggers - such as tectonics and/or earthquakes - were probably required to destabilize these deposits and initiate the Gebra Slide.

- This is the first recent (i.e. post-dating the last glacial period) submarine slide of this scale identified on the Antarctic continental margin. In morphology and general characteristics it is quite similar to the various large-scale submarine slides known from the North Atlantic glacial margins, although it is significantly smaller. The most striking difference, however, is its position on the low- er slope, which up to now remains difficult to explain.

\section{Acknowledgements}

This study was supported by the Belgian Antarctic Research Programme (Project A4/DD/ GO1) and by the Spanish Programa Nacional de Investigacion Antartica (project MAGIA ANT970584 and ANTR99-1462-E). CRG Marine Geosciences is funded by the autonomous Catalan government. Credit is also given to the Spanish project COHIMAR (REN2000-0896/Ant). We thank the captains and crews of $\mathrm{R} / \mathrm{V}$ Hesperides and our colleagues who participated in the cruises during which the data were collected. M.L. Farràn and $\mathrm{W}$. Versteeg are gratefully acknowledged for processing the bathymetric and seismic data. We would also like to thank A. Maldonado, J.S. Laberg and D. Piper for their constructive comments which helped to improve the manuscript. Y.I. is funded by a Ph.D. grant of the Flemish IWT (Brussels).

\section{References}

Aksu, A.E., Hiscott, R.N., 1992. Shingled Quaternary debris flow lenses on the north-east Newfoundland Slope. Sedimentology 39, 193-206.

Alley, R.B., Blankenship, D.D., Rooney, S.T., Bentley, C.R., 1989. Sedimentation beneath Ice Shelves - The View from Ice Stream B. Mar. Geol. 85, 101-120.

Banfield, L.A., Anderson, J.B., 1995. Seismic facies investigation of the Late Quaternary glacial history of Bransfield Basin, Antarctica. In: Cooper, A.K., Barker, P.F., Brancolini, G. (Eds.), Geology and seismic Stratigraphy of the Antarctic Margin. AGU Antarctic Research Series 68, pp. 123140 .

Barker, D.H.N., Austin, J.A.A., 1998. Rift propagation, detached faulting, and associated magmatism in Bransfield Strait, Antarctic Peninsula. J. Geophys. Res. 103, $24017-$ 24043.

Barker, P.F., 1982. The Cenozoic subduction history of the Pacific margin of the Antarctic Peninsula: Ridge cresttrench interactions. J. Geol. Soc. London 139, 787-801.

Bart, P.J., De Batist, M., Jokat, W., 1999. Interglacial collapse of Crary Trough-Mouth Fan, Weddell Sea, Antarctica: Implications for Antarctic glacial history. J. Sediment. Res. 69, 1276-1289.

Brachfeld, S.A., Banerjee, S.K., Guyodo, Y., Acton, G., 2002. 
A 13200 year history of century to millennial-scale paleoenvironment change magnetically recorded in the Palmer Deep, western Antarctic Peninsula. Earth Planet. Sci. Lett. 194, 311-326.

Bugge, T., Befring, S., Belderson, R.H., Eidvin, T., Jansen, E., Kenyon, N.H., Holtedahl, H., Sejrup, H.P., 1987. A giant three-stage submarine slide off Norway. Geo-Mar. Lett. 7, 191-198.

Canals, M., Acosta, J., Baraza, J., Bart, P., Calafat, A.M., Casamor, J.L., De Batist, M., Ercilla, G., Farràn, M., Franes, G., Gràcia, E., Ramos-Guerrero, E., Sanz, J.L., Sorribas, J.L., Tassone, A., 1994. La Cuenca Central de Bransfield (NW de la Península Antártica): primeros resultados de la campaòa GEBRA-93. Geogaceta 16, 132-135.

Canals, M., Urgeles, R., Calafat, A.M., 2000. Deep sea-floor evidence of past ice streams off the Antarctic Peninsula. Geology 28, 31-34.

Canals, M., Casamor, J.L., Urgeles, R., Calafat, A.M., Domack, E.W., Baraza, J., Farràn, M., De Batist, M., 2002. Seafloor evidence of a subglacial sedimentary system off the northern Antarctic Peninsula. Geology 30, 603-606.

Dimakis, P., Elverhøi, A., Hoeg, K., Solheim, A., Harbitz, C., Laberg, J.S., Vorren, T.O., Marr, J., 2000. Submarine slope stability on high-latitude glaciated Svalbard-Barents Sea Margin. Mar. Geol. 162, 303-316.

Dowdeswell, J.A., Siegert, M.J., 1999. Ice-sheet numerical modeling and marine geophysical measurements of glacierderived sedimentation on the Eurasian Arctic continental margins. Geol. Soc. Am. Bull. 111, 1080-1097.

Elverhøi, A., Norem, H., Anderson, E.S., Dowdeswell, J.A., Fossen, I., Haflidason, H., Kenyon, N.H., Laberg, J.S., King, E.L., Sejrup, H.P., Solheim, A., Vorren, T., 1997. On the origin and flow behavior of submarine slides on deep-sea fans along the Norwegian-Barents Sea continental margin. Geo-Mar. Lett. 17, 119-125.

Ercilla, G., Baraza, J., Alonso, B., Canals, M., 1998. Recent geological processes in the Central Bransfield Basin (Western Antarctic Peninsula). In: Stoker, M.S., Evans, D., Cramps, A. (Eds.), Geological Processes on Continental Margins: Sedimentation, Mass-Wasting and Stability. Geol. Soc. London Spec. Publ. 129, pp. 205-216.

Escutia, C., Eittreim, S.L., Cooper, A.K., Nelson, C.H., 2000. Morphology and acoustic character of the Antarctic Wilkes Land turbidite systems: Ice-sheet-sourced versus riversourced fans. J. Sediment. Res. 70, 84-93.

Faugères, J.-C., Gonthier, E., Mulder, T., Kenyon, N., Cirac, P., Griboulard, R., Berné, S., Lesuave, R., 2002. Multi-process generated sediment waves on the Landes Plateau (Bay of Biscay, North Atlantic). Mar. Geol. 182, 279-302.

Gambôa, L.A.P., Maldonado, P.R., 1990. Geophysical investigations in the Bransfield Strait and in the Bellingshausen Sea - Antarctica. In: St. John, B. (Ed.), Antarctica as an Exploration Frontier - Hydrocarbon Potential, Geology, and Hazards. AAPG Stud. Geol. 31, 13-29.

Gardner, J.V., Prior, D.B., Field, M.E., 1999. Humboldt Slide - a large shear-dominated retrogressive slope failure. Mar. Geol. 154, 323-338.
Gee, M.J.R., Watts, A.B., Masson, D.G., Mitchell, N.C., 2001. Landslides and the evolution of El Hierro in the Canary Islands. Mar. Geol. 177, 271-293.

Gràcia, E., Canals, M., Farràn, M.L., Prieto, M.J., Sorribas, J., GEBRA Team, 1996. Morphostructure and evolution of the central and eastern Bransfield Basins (NW Antarctic Peninsula). Mar. Geophys. Res. 18, 429-448.

Gràcia, E., Canals, M., Farràn, M.L., Sorribas, J., Pallàs, R., 1997. Central and eastern Bransfield Basins (Antarctica) from high-resolution swath-bathymetry data. Antarct. Sci. 9, 168-180.

Harden, S.L., Demaster, D.J., Nittrouer, C.A., 1992. Developing sediment geochronologies for high-latitude continental shelf deposits: a radiochemical approach. Mar. Geol. 103, 69-97.

Henriet, J.P., Meissner, R., Miller, H., GRAPE Team, 1992. Active margin processes along Antarctic Peninsula. Tectonophysics 201, 1-25.

Howe, J.A., Livermore, R.A., Maldonado, A., 1998. Mudwave activity and current-controlled sedimentation in Powell Basin, northern Weddell Sea, Antarctica. Mar. Geol. 149, 229 241.

Hughes Clarke, J.E., O’Leary, D., Piper, D.J.W., 1992. The relative importance of mass wasting and deep boundary current activity on the continental rise off Western Nova Scotia. In: Poag, C.W., de Gràciansky, P.C. (Eds.), Geologic Evolution of Antlantic Continental Rises. Van Nostrand Reinhold, New York, pp. 266-281.

Ibañez, J.M., Morales, J., Alguacil, G., Almendros, J., Ortiz, R., DelPezzo, E., 1997. Intermediate-focus earthquakes under South Shetland Islands (Antarctica). Geophys. Res. Lett. 24, 531-534.

Jeffers, J.D., Anderson, J.B., 1990. Sequence stratigraphy of the Bransfield Basin, Antarctica: Implications for tectonic history and hydrocarbon potential. In: St. John, B. (Ed.), Antarctica as an Exploration Frontier - Hydrocarbon Potential, Geology, and Hazards. AAPG Stud. Geol. 31, pp. 13-29.

Jin, Y.K., Lee, D.K., Nam, S.H., Kim, Y., Kim, K.J., 1998. Seismic observation at King Sejong Station, Antarctic Peninsula. Terra Antarct. 5, 729-736.

Laberg, J.S., Vorren, T.O., 1993. A Late Pleistocene submarine slide on the Bear Island Trough Mouth Fan. Geo-Mar. Lett. $13,227-234$

Laberg, J.S., Vorren, T.O., 1995. Late Weichselian submarine debris flow deposits on the Bear Island Trough Mouth Fan. Mar. Geol. 127, 45-72.

Laberg, J.S., Vorren, T.O., 2000a. The Trænadjupet Slide, offshore Norway - morphology, evacuation and triggering mechanisms. Mar. Geol. 171, 95-114.

Laberg, J.S., Vorren, T.O., 2000b. Flow behavior of the submarine glacigenic debris flows on the Bear Island Trough Mouth Fan, western Barents Sea. Sedimentology 47, 11051117

Laberg, J.S., Vorren, T.O., Dowdeswell, J.A., Kenyon, N.H., Taylor, J., 2000. The Andøya Slide and the Andøya Canyon, north-eastern Norwegian-Greenland Sea. Mar. Geol. $162,259-275$. 
Laberg, J.S., Vorren, T.O., Mienert, J., Bryn, P., Lien, R., 2002a. The Traenadjupet Slide: a large slope failure affecting the continental margin of Norway 4,000 years ago. GeoMar. Lett. 22, 19-24.

Laberg, J.S., Vorren, T.O., Mienert, J., Evans, D., Lindberg, B., Ottesen, D., Kenyon, N.H., Henriksen, S., 2002b. Late Quaternary palaeoenvironment and chronology in the Trænadjupet Slide area offshore Norway. Mar. Geol. 188, $35-60$.

Larter, R.D., Barker, P.F., 1991. Neogene interaction of tectonic and glacial processes at the Pacific margin of the Antarctic Peninsula. In: MacDonald, D.I.M. (Ed.), Sedimentation, Tectonics and Eustasy: Sea Level Changes at Active Margins. Int. Assoc. Sediment. Spec. Publ. 12, Blackwell Scientific, Oxford, pp. 165-186.

Locat, J., 2001. Instabilities along ocean margins: a geomorphological and geotechnical perspective. Mar. Petrol. Geol. $18,503-512$.

Locat, J., Lee, H.L., 2000. Submarine landslides. Proc. 8th Int. Symp. on Landslides, Cardiff, pp. 1-30.

Lodolo, E., Camerlenghi, A., Brancolini, G., 1993. A bottom simulating reflector on the South Shetland margin, Antarctic Peninsula. Antarct. Sci. 5, 207-210.

Masson, D.G., Canals, M., Alonso, B., Urgeles, R., Huhnerbach, V., 1998. The Canary Debris Flow: source area morphology and failure mechanisms. Sedimentology 45, 411432.

McGinnis, J.P., Hayes, D.E., 1995. The roles of downslope and along-slope depositional processes: Southern Antarctic Peninsula continental rise. Antarct. Res. Ser. 68, 141-156.

McGinnis, J.P., Hayes, D.E., Driscoll, N.W., 1997. Sedimentary processes across the continental rise of the southern Antarctic Peninsula. Mar. Geol. 141, 91-109.

Mosher, D.C., Moran, K., Hiscott, R.N., 1994. Late Quaternary sediment, sediment mass flow processes and slope stability on the Scotian Slope, Canada. Sedimentology 41, 1039-1061.

Mulder, T., Cochonat, P., 1996. Classification of offshore mass movements. J. Sediment. Res. 66, 43-57.

Mulder, T., Moran, K., 1995. Relationship among submarine instabilities, sea level variations, and the presence of an ice sheet on the continental shelf: An example from the Verrill Canyon Area, Scotian Shelf. Paleoceanography 10, 137-154.

Nitsche, F.O., Cunningham, A.P., Larter, R.D., Gohl, K., 2000. Geometry and development of glacial continental margin depositional systems in the Bellingshausen Sea. Mar. Geol. 162, 277-302.
Pelayo, A.M., Wiens, D.A., 1989. Seismotectonics and relative plate motions in the Scotia Sea Region. J. Geophys. Res. 94, 7293-7320.

Piper, D.J.W., Cochonat, P., Morrison, M.L., 1999. The sequence of events around the epicentre of the 1929 Grand Banks earthquake: initiation of debris flows and turbidity current inferred from sidescan sonar. Sedimentology 46, 7998.

Prieto, M.J., Ercilla, E., Canals, M., De Batist, M., 1999. Seismic stratigraphy of the Central Bransfield Basin (NW Antarctic Peninsula): interpretation of deposits and sedimentary processes in a glacio-marine environment. Mar. Geol. 157, 47-68.

Prieto, M.J., Canals, M., Ercilla, G., De Batist, M., 1998. Structure and geodynamic evolution of the Central Bransfield Basin (NW Antarctica) from seismic reflection data. Mar. Geol. 149, 17-38.

Pudsey, C.J., Barker, P.F., Larter, R.D., 1994. Ice sheet retreat from the Antarctic Peninsula Shelf. Cont. Shelf Res. 14, 1647-1675.

Pudsey, C.J., Camerlenghi, A., 1998. Glacial-interglacial deposition on a sediment drift on the Pacific margin of the Antarctic Peninsula. Antarct. Sci. 10, 286-308.

Savoye, B., Cochonat, P., Piper, D.J.W., 1990. Seismic evidence for a complex slide near the Titanic wreck: model of an instability corridor for non-channelised gravity events. Mar. Geol. 91, 281-298.

Szeliga, J., 1990. Bathymetric map of Bransfield Strait 1:700,000. Institute of Ecology, Polish Academia of Sciences, Warsaw.

Viseras, C., Maldonado, A., 1999. Facies architecture, seismic stratigraphy and development of a high-latitude basin: the Powell Basin (Antarctica). Mar. Geol. 157, 69-87.

Vorren, T.O., Laberg, J.S., 1997. Trough mouth fans - palaeoclimate and ice sheet monitors. Quat. Sci. Rev. 16, 865-881.

Vorren, T.O., Laberg, J.S., Blaume, F., Dowdeswell, J.A., Kenyon, N.H., Mienert, J., Rumohr, J., Werner, F., 1998. The Norwegian-Greenland Sea continental margins: Morphology and Late Quaternary sedimentary processes and environment. Quat. Sci. Rev. 17, 273-302.

Weaver, P.P.E., Wynn, R.B., Kenyon, N.H., Evans, J., 2000. Continental margin sedimentation, with special reference to the north-east Atlantic margin. Sedimentology 47 (suppl. 1), 239-356.

Yoon, H.I., Han, M.W., Park, B.K., Oh, J.K., Chang, S.K., 1994. Depositional environment of near-surface sediments, King George Basin, Bransfield Strait, Antarctica. Geo-Mar. Lett. 14, 1-9. 